\title{
The effect of yeast (Saccharomyces cerevisiae) on fattening performances of growing cattle
}

\begin{abstract}
The aim of this experiment was to evaluate the yeast on fattening performances of the growing cattle. The experiment was carried out with 179 imported 12-14 months old growing different breed bulls (Hereford, Angus, Brangus, and some other crossbreds) that were allocated to control and yeast group according to the breeds and body weight. Experimental diet was formulated with $19 \%$ roughages (alfalfa and wheat straw) containing $13 \%$ crude protein. Yeast group was supplemented $40 \mathrm{~g} \mathrm{~d}^{-1}$ live yeast containing $1.23 \times 10^{11} \mathrm{CFU} / \mathrm{g}$. The study lasted 62 days from May to July. Initial body weight were 393.91 $\pm 4,43$ for control and $395.56 \pm 4.45 \mathrm{~kg}$ for yeast group. After test period, daily gain was similar $(1465.85 \pm 26.76$ vs. $1451.42 \pm 34.05 \mathrm{~g} \mathrm{~d}^{-1}, \mathrm{P}>0.05$ ) for the bull receiving the diet without yeast compared to the bulls receiving yeast. Similar results were obtained for feed to gain ratio $(\mathrm{P}>0.05)$ as well. In conclusion, under present experimental condition (high concentrate, buffer usage and better total mixed ration management) the yeast (Saccharomyces cerevisiae) did not improve fattening performance of growing cattle.
\end{abstract}

Keywords: growing cattle, bull, yeast, Saccharomyces cerevisiae, fattening performance
Volume 5 Issue 3 - 2020

\author{
Serap Göncü,' Sibel Bozkurt,' Murat \\ Görgülü²। \\ 'Animal science, Çukurova University, Turkey \\ ${ }^{2}$ Ruminant Nutrition, Makrovit Hayvan Besleme Teknolojileri \\ Ltd.Sti. Konya/Turkey \\ Correspondence: Serap Göncü, Animal science, Cukurova \\ University, Turkey, Tel 905333606282 , \\ Email Serapgoncu66@gmail.com
}

Received: February 20, 2020 | Published: May 19, 2020

\section{Introduction}

The main purpose of activity in all type of animal husbandry is to make profit. Numerous research over the years have successfully led to substantial improvements in growth rate, days on feed, carcass weight and feed to gain in cattle fattening operations. Last 30 years, marked improvements were due to studies on diet, management and growth promoters. Profitability depends on the performance of the animals. Ruminant performances mainly depend on rumen fermentation conditions. Many applications (buffer, prebiotics, probiotics, synchronous nutrient supply, roughage particle size and diet moisture content, essential oil etc.) are available on the practice for better rumen activity and better performances. ${ }^{1}$ The studies interested in ruminant feeding focused on manipulation of rumen fermentation and the rumen ecosystem in order to increase the efficiency of nutrient utilization in the ruminally and postruminally. Fattening diets contain high concentrate and it may decrease rumen $\mathrm{pH}$ resulting in decrease in cellulose digestion, increasing diarrhea, bloat, laminitis risk and interfering microbial growth in the rumen. All these effects may decrease fattening performance of growing cattle.

Direct fed microorganisms have been used in recent years to improve the efficiency of rumen fermentation and to increase the efficiency of nutrient utilization in ruminants. The yeast usage is one of the most applicable and safest feed additives in the ruminant nutrition for better performances. ${ }^{2}$ This idea suggested that the yeast cultures encouraged the growth of helpful bacteria (e.g. cellulolytic, acid utilizing bacteria, Chaucheyras et al. ${ }^{3}$ ), which improve rumen condition and nutrient utilization efficiency. In recent studies with different yeast species, it has been emphasized that the increase in the number of viable microorganisms in the rumen is caused by the respiratory activities of the yeast in the rumen, thus removing the oxygen present in the rumen and providing an anaerobic environment for strictly anaerobic microorganisms in the rumen. Aspergillus oryzae group is used both live and dead with fermentation medium and can contribute to the rapid proliferation of rumen microorganisms $s^{4,5}$ as well. Some authors investigated the effect of adding live yeast in ruminant diet and found no positive results while other positive. Krehbiel et al., ${ }^{6}$ indicated that feeding of direct-fed microbials (DFM) to feedlot cattle generally results in increase feed intake and daily weight gain and improvement in feed efficiency. However, Brashears et al. ${ }^{7}$ reported that supplementation of DFM resulted in no measurable impact on growth rate in finishing cattle.

The aim of this experiment was to evaluate the live yeast supplementation effects at intensive fattening performances of different breed growing bulls.

\section{Materials and methods}

This study was conducted with Angus, Hereford, Brangus and different crossbreed 10-14 months of age bulls during the 62 days period from May and July. The experiment was carried out a Şanal Agricultural Enterprises intensive fattening farm is located $30 \mathrm{~km}$ from Adana which is located between 35-38 latitude and 34-46 eastern longitude and in Mediterranean Region with a total 179 head growing cattle. The farm had 9 pen sized $18 \times 12 \mathrm{~m}$ and 4 pens were used to test supplemental yeast on fattening performance of growing cattle. Each pen had $18 \mathrm{~m}$ feeding space. The intensive fattening farm has a capacity of 400 heads and is designed free semi-open barn.

The total mixed ration (TMR) was formulated to get $1700 \mathrm{~g} / \mathrm{day}^{8}$ with barley, corn flake, protein concentrate, wheat straw and alfalfa hay with $19.53 \%$ roughage, $13.03 \%$ crude protein (Table 1 ). The same TMR was offered three times a day at 06:00, 14:00 and 22:00 according to animal number and size in each pen ad libitum for two experimental groups, control and yeast groups. Yeast group was supplemented with $40 \mathrm{~g}$ yeast containing $1.23 \times 10^{11} \mathrm{CFU}$ active yeast and $215 \mathrm{mg}$ inactive yeast culture (cell wall extract) per gram. 
Table I The total mixed ration used throughout study

\begin{tabular}{ll}
\hline Feeds & \%DM \\
\hline Barley & 31,33 \\
Corn Flake & 30,30 \\
Protein concentrate** & 19,13 \\
Alfalfa & 15,66 \\
Wheat Straw & 3,57 \\
Total & 100,00 \\
Nutrient compositions & \\
Dry matter (\% As fed)* & 62,34 \\
Roughage (\% DM) & 19,53 \\
Crude protein (\% DM) & 13,03 \\
Fat(\%DM) & 2,70 \\
Ash(\%DM) & 8,73 \\
NDF(\%DM) & 23,40 \\
\hline
\end{tabular}

*TMR dry matter content adjusted $62,34 \%$ by adding water to mixer wagon

** protein concentrate contains $4 \%$ limestone, $4 \%$ sodium bicarbonate and $\% 2$ magnesium oxide, $1 \%$ salt and $0.3 \%$ vitamin mineral premix
Feed intake was and feed was determined in pen based and feed to gain ratio was calculated from pen average dry matter intake and individual daily gains. In order to meet the salt needs of bulls, licking stones were kept in the feeders continuously. The fresh water was supplied to the bulls in the waterer in each paddock. Daily gain was determined with 4 week period by weighing all animal before feeding.

Feed analysis was determined according to methods described in AOAC. ${ }^{9}$ Body weight, daily gains and feed to gain ratio were analyzed statistically with completely randomized design using the SPSS statistical package program. ${ }^{10}$

\section{Results and discussion}

Overall fattening performances of the experimental groups are presented in Table 2. Daily gain, feed intake and feed to gain were not affected from yeast (Sacchoromyces cerevisia). Dry matter intake, daily gain and feed to gain were $11.36 \mathrm{~kg} v s .11 .46 \mathrm{~kg} \mathrm{~d}^{-1} ; 1465$, $85 \pm 26,76$ vs. $1451,842 \pm 34.05$ and $8.04 \pm 0.18 v s$. $8.33 \pm 0.24$ for control and yeast supplemented bulls respectively. Ovinge et al. ${ }^{11}$ revealed that growth performance of steers fed steam-flaked corn-based finishing diets. Similar results were observed in cattle, ${ }^{12,13}$ sheep ${ }^{14}$ and lambs. ${ }^{15-17}$

Table 2 Overall fattening performances data of the experimental groups

\begin{tabular}{|c|c|c|c|c|c|c|c|}
\hline \multirow{2}{*}{$\begin{array}{l}\text { Fattening performance } \\
\text { parameters }\end{array}$} & \multicolumn{3}{|l|}{ Control group } & \multicolumn{3}{|c|}{ Treatment (Yeast) group } & \multirow{2}{*}{$\begin{array}{l}\text { Sig. } \\
\mathbf{P}<\end{array}$} \\
\hline & $\overline{\mathbf{x} \pm S} \bar{x}$ & Min & $\operatorname{Max}$ & $\overline{\mathbf{x} \pm S x}$ & Min & Max & \\
\hline Number of animal & 94 & & & 85 & & & \\
\hline Initial body weight (kg) & $393,91 \pm 4,43$ & 261 & 519 & $395,56 \pm 4,45$ & 306 & 497 & 0,75 \\
\hline Final body weight (kg) & $484,80 \pm 5.00$ & 365 & 639 & $485,55 \pm 5,35$ & 368 & 600 & 0,92 \\
\hline Daily gain (g d-I) & $\mid 465,85 \pm 26,76$ & 693,55 & 2000 & $|45|, 42 \pm 34.05$ & 596.77 & 2274,19 & 0,74 \\
\hline Dry matter intake $(\mathrm{kg} \mathrm{d}-\mathrm{I})^{*}$ & 11,36 & $|I, 0|$ & 11,66 & 11,46 & $1 \mathrm{I}, 02$ & 11,93 & \\
\hline Feed to Gain** & $8,04 \pm 0,18$ & 5,69 & 15,87 & $8,33 \pm 0,24$ & 5.25 & 18.47 & 0,32 \\
\hline
\end{tabular}

* Two pen feed intake exist for each treatment as group basis, thus statistic analysis was not performed for dry matter intake

** The feed to gain ratio was calculated by the amount of dry matter intake per kg daily gain for each bull

However some other studies reported that Saccharomyces cerevisiae supplemented to ruminants can affect dry matter intake, rumen $\mathrm{pH}$ and overall nutrient digestibility. ${ }^{18-21}$ Finck et al. ${ }^{22}$ reported increases in dry matter intake in cattle during the receiving period at the feedlot when cattle were supplemented with yeast products. Other studies utilizing supplementation with yeast products have also reported increases in dry matter intake and average daily gain of feeder cattle. ${ }^{11}$ Lack of response to yeast supplementation in the present study may be attributed to no improvement in nutrient digestibility. The diet based on alfalfa hay as main forage which has high pectin content of alfalfa hay with high buffering capacity, ${ }^{23}$ protein concentrate used in the study supplied about $100 \mathrm{~g} \mathrm{~d}^{-1}$ and $50 \mathrm{~g} \mathrm{~d}^{-1}$ sodium bicarbonate and magnesium oxide as buffer. Additionally good feed bunk management with optimum particle size supplying enough effective NDF and TMR moisture to prevent sorting behavior of bull in the present study may prevent advantages of yeast supplementation over control.

As reported before, the studies in literature with live yeast supplementation have inconsistent results for ruminants due to differences in animal material, diet, yeast culture, feeding management, other feed additives usage together with yeast. ${ }^{4,15}$
Furthermore, the modes of action of yeast products that directly or indirectly affecting metabolic and performance changes have not been fully elucidated. ${ }^{24-27}$

\section{Conclusion}

Yeast (Saccharomyces cerevisiae) supplementation did not improve fattening performance of bull in the present study. Lack of response to yeast supplementation to TMR of fattening bull may be attributed to forage source, buffer supply $\left(\mathrm{NaHCO}_{3}, \mathrm{MgO}\right)$, good feed bunk management (ad libitum feeding, proper particle size and diet moisture for preventing sorting behavior).

\section{Acknowledgments}

The authors thank to Şanal Agricultural Enterprises for permission and support for the carrying study and Makrovit Animal Nutrition Technologies Industry and Trade Inc. for supplying yeast product.

\section{Funding}

None. 


\section{Conflicts of interest}

The authors declare there are no conflicts of interest.

\section{References}

1. Newbold CJ, Mcmtosh FM, Wallace RJ. Mode of action of the yeast. Saccharomyces cerevisiae, as a feed additive for ruminants. British Journal of Nutrition. 1996;76:249-261.

2. Newbold CJ. Probiotics for ruminants. In: Wallace J, Chesson A, editors. Biotechnology in animal feeds and animal nutrition. Weinheim, Germany: VCH Verlagsgesellschaft mbH; 1995:259-278.

3. Chaucheyras F, Fonty G, Bertin G, et al. Effects of a strain of Saccharomyces cerevisiae (Levucell SC), a microbial additive for ruminants, on lactate metabolism in vitro. Can J Microbiol. 1995;42(9):927-933.

4. Tricarico JM, Abney MD, Galyean ML, et al. Effects of a dietary Aspergillus oryzae extract containing alpha-amylase activity on performance and carcass characteristics of finishing beef cattle. J Anim Sci. 2007;85:802-811.

5. Tricarico JM, Johnston JD, Dawson KA. Dietary supplementation of ruminant diets with an Aspergillus oryzae alpha-amylase. Anim Feed Sci Tech. 2008;145:136-150.

6. Krehbiel CR, Rust SR, Zhang G, et al. Bacterial direct-fed microbials in ruminant diets: Performance response and mode of action. J Anim Sci. 2003;81(E.Suppl.2):E120-E132.

7. Brashears MM, Amezquita A, Jaroni D. Lactic acid bacteria and their uses in animal feeding to improve food safety. Adv Food Nutr Res. 2005;50:131

8. NRC. Nutrient requirements beef cattle. 7 th ed. Washington, DC: National Academy Press; 1996.

9. AOAC. Official Methods of Analysis. In: Horney MR, DelCurto T, Stamm MM, editors. 15th ed. Association of Official Analytical Chemist. Inc Arlington, Virginia; 1990.

10. SPSS. SPSS for windows Release 21.0. Chicago, IL: SPSS Inc; 2019.

11. Ovinge LA, Sarturi JO, Galyean ML, et al. Effects of a live yeast in natural-program finishing feedlot diets on growth performance, digestibility, carcass characteristics, and feeding behavior. J Anim Sci. 2018;96(2):684-693

12. Phillips WA, von Tungeln DL. The effect of yeast culture on the poststress performance of feeder calves. Nutr Rep Int. 1985;32:287.

13. Gumus, H, Sehu, A. The effect of adding yeast culture to fattening rations on fattening performance and some rumen and blood parameters. Ankara Üniv Vet Fak Derg. 2016;63:39-46.

14. Macedo R, Arredondo V, Beauregard, J. Influence of yeast culture on productive performance of intensively fattened Pelibuey lambs in Colima, México. Avances En Investigación Agropecuaria. 2006;10:59-67.
15. Mikulec ŽZ, Mašek $T$, Habrun $B$, et al. Influence of live yeast cells (Saccharomyces cerevisiae) supplementation to the diet of fattening lambs on growth performance and rumen bacterial number. Veterinarski arhiv. 2010;80:695-703.

16. Kawas JR, Carcia-Castillo R, Garza-Cazares F, et al. Effects of sodium bicarbonate and yeast on productive performance and carcass characteristics of light-weight lambs fed finishing diets. Small Ruminant Research. 2007;67:157-163.

17. Titi HH, Dmour RO, Abdullah AY. Growth performance and carcass characteristics of Awassi lambs and Shami goat kids fed yeast culture in their finishing diet. Animal Feed Science and Technology. 2008;142:3343.

18. Callaway E, Martin S. Effects of a saccharomyces cerevisiae culture on ruminal bacteria that utilize lactate and digest cellulose. J Dairy Sci. 1997;80(9):2035-2044.

19. Dann H, Drackley J, McCoy G, et al. Effects of yeast culture (Saccharomyces cerevisiae) on prepartum intake and postpartum intake and milk production of jersey cows. J Dairy Sci. 2000;83(1):123-127.

20. Haddad SG, Goussous SN. Effects of yeast culture supplementation on nutrient intake digestibility and growth performance of Awassi lambs. Animal Feed Science and Technology. 2004;118:343-348.

21. Kamal R, Dutt T, Mukesh Singh M, et al. Effect of live Saccharomyces cerevisiae (NCDC-49) supplementation on growth performance and rumen fermentation pattern in local goat. Journal of Applied Animal Research. 2013;41(3):285-288.

22. Finck D, Ribeiro F, Burdick N, et al. Yeast supplementation alters the performance and health status of receiving cattle. Prof Anim Sci. 2014;30(3):333-341.

23. Van Soest PJ, Robertson JB, Lewis BA. Methods for dietary fiber, neutral detergent fiber, and non starch polysaccharides in relation to animal nutrition. J Dairy Sci. 1991;74:3583-3597.

24. Elam NA, Gleghorn JF, Rivera JD, et al. Effects of live cultures of Lactobacillus acidophilus and Propionibacterium freudenreichii on performance, carcass, and intestinal characteristics and Escherichia coli strain 0157 shedding of finishing beef steers. J Anim Sci. 2003;81(11):2686-2698.

25. Gritzer K, Leitgeb R. Evaluation of the effectiveness of antibiotic and probiotic growth promoters on the performance of fattening bulls. Bodenkultur. 1998;49:51-59.

26. Issakowicz J, Bueno MS, Sampaio ACK, et al. Effect of concentrate level and live yeast (Saccharomyces cerevisiae) supplementation on Texel lamb performance and carcass characteristics. Livestock Science. 2013;155:44-52.

27. Jukna C, Jukna V, Simkus A. The influence of probiotics andphytobiotics on meat characteristics and quality of fattening bulls. Veterinarjia ir Zootechnika. 2005;29:76-79. 